\title{
PERSEPSI GURU SEKOLAH DASAR TENTANG IMPLEMENTASI PENDIDIKAN KARAKTER DI WILAYAH III KECAMATAN KEBAYORAN BARU JAKARTA SELATAN
}

\author{
Nur Wahyuni \\ FKIP Universitas Prof.Dr.Hamka Jakarta \\ Email : wahyuni222@gmail.com, Hp. 08128124742
}

\begin{abstract}
Abstrak
Penelitian ini bertujuan untuk mengetahui persepsi guru sekolah dasar terhadap pendidikan karakter di Wilayah III, Kecamatan Kebayoran Baru, Jakarta Selatan. Subjek penelitian ini adalah guru sekolah dasar Wilayah III, Kecamatan Kebayoran Baru, Jakarta Selatan. Objek penelitiannya adalah persepsi guru terhadap pendidikan karakter. Penelitian ini menggunakan pendekatan deskriptif kuantitatif. Teknik analisis data yang digunakan adalah teknik deskriptif kuantitatif menggunakan UjiT. Hasil penelitian menunjukkan bahwa secara keseluruhan persepsi guru Sekolah Dasar di di Wilayah III, Kecamatan Kebayoran Baru, Jakarta Selatan terhadap pendidikan karakter hipotesis (H1) diterima artinya ada perbedaan persepsi antara guru yang berpengalaman dan yang belum berpengalaman dalam implementasi pendidikan karakter. Karena angka yang diperoleh dalam penelitian $t_{\text {hitung }}$ lebih besar dari $t_{\text {tabel }}\left(t_{\text {hitung }}>t_{\text {tabel }} ; 4,182>\right.$ $2,000)$. Hasil perhitungan $t_{\text {hitung }}$ yang lebih besar dari pada $t_{\text {tabel }}$ juga dapat dilihat dari hasil rata-rata skor angket guru yang berpengalaman lebih besar yakni 131,67 sedangkan hasil rata-rata skor angket guru yang tidak berpengalaman adalah sebesar 126.5.
\end{abstract}

Kata kunci: persepsi guru terhadap pendidikan karakter. 


\begin{abstract}
This study about aimed to determine the perceptions of elementary school teachers on character education in Region III, District Kebayoran Baru, South Jakarta. The subjects were elementary school teachers Region III, District Kebayoran Baru, South Jakarta. The research object is the teacher's perception of the character education. This study used a descriptive quantitative approach. The data analysis technique used is descriptive quantitative techniques using $T$ - test. The results showed that the overall perception of elementary school teachers in Region III, District Kebayoran Baru, South Jakarta, to the education of character hypothesis (H1) in the received meaning there is a difference in perception between teachers who are experienced and who have not experienced in the implementation of character education. Because the numbers obtained in the study t_hitung greater than penelitian $t_{\text {hitung }}$ lebih besar dari $t_{\text {tabel }}\left(t_{\text {hitung }}>t_{\text {tabel }} ; 4,182>2,000\right)$. T_hitung calculation results are greater than $t_{-}$(table) can also be seen from the results of the average experienced teacher questionnaire scores greater the 131.67 while the average yield scores inexperienced teacher questionnaire amounted to 126.5 .
\end{abstract}

Keywords: teacher's perception of the character education

\title{
Pendahuluan
}

Undang-undang No 20 Tahun 2003 Tentang Sistem Pendidikan Nasional, menyebutkan bahwa pendidikan nasional berfungsi mengembangkan kemampuan dan membentuk karakter serta peradaban bangsa yang bermartabat dalam rangka mencerdaskan kehidupan bangsa. Oleh karena itu bangsa Indonesia yang selalu berbenah dalam aspek pendidikan dengan selalu memperbaiki sistem pendidikannya. Yang tak jarang selalu mengganti kebijakan tentang kurikulum dalam waktu yang cukup singkat, kurikulum sebagai jantungnya pendidikan (curriculum is the heart of education).

Hal ini sangat mendasar, karena tugas guru bukan hanya mengajar (transfer of knowledge) tetapi juga menanamkan nilai- 
nilai karakter dan akhlak mulia (transfer of values). Tidak bisa dipungkiri bahwa sebagian besar guru di Indonesia belum layak mengajar itu pun didominasi oleh guru-guru yang sudah senior dan sisanya masih perlu pembenahan. Hal tersebut dikarenakan kurangnya pelatihan skill dalam mengajar, kurangnya pembinaan terhadap kurikulum yang terbaru, kurangnya pemahaman guru tentang mengintegrasikan nilai-nilai karakter dalam pembelajaran.

Pendidikan karakter diintegrasikan ke kurikulum dan silabus, sebagian guru kita kelabakan untuk menentukan pengertian karakter itu sendiri. Kerisauan guru-guru dalam menerapkan materi pelajaran yang mengintegrasikan nilai-nilai karakter merupakan potret nyata bahwa selama ini pendidikan di Indonesia hanya pandai mencerdaskan otak (kognitif), namun gagal dalam membentuk siswa yang berkarakter (afektif).

Pembentukan karakter itu dimulai dari fitrah yang diberikan Tuhan, yang kemudian membentuk jati diri dan perilaku. Dalam prosesnya sendiri fitrah yang alamiah ini sangat dipengaruhi oleh keadaan lingkungan, sehingga lingkungan memilki peranan yang cukup besar dalam membentuk jati diri dan perilaku. Sekolah dan masyarakat sebagai bagian dari lingkungan memiliki peranan yang sangat penting, oleh karena itu setiap sekolah dan masyarakat harus memiliki disiplin dan kebiasaan mengenai karakter yang akan dibentuk. Para pemimpin dan tokoh masyarakat juga harus mampu memberikan suri teladan mengenai karakter yang akan dibentuk.

Pendidikan karakter dapat diintegrasikan dalam pembelajaran pada setiap mata pelajaran. Materi pembelajaran yang berkaitan dengan norma atau nilai-nilai pada setiap mata pelajaran perlu dikembangkan, dikaitkan dengan konteks kehidupan sehari-hari. Dengan demikian, pembelajaran nilai-nilai karakter tidak hanya 
pada tataran kognitif, tetapi menyentuh pada internalisasi dan pengamalan nyata dalam kehidupan peserta didik sehari-hari di masyarakat.

Sekarang timbul masalah baru yang cukup pelik tentang pemahaman atau persepsi antar sesama guru tentang implementasi pendidikan karakter. Mulai dari perbedaan pendapat, perbedaan pandangan dan perbedaan persepsi tentang bagaimana menerapkan dan mengintegrasikan dalam proses pembalajaran. Hasil dari wawancara peneliti terhadap beberapa guru baik yang berpengalaman maupun guru yang berpengalaman di sekolah dasar menyebutkan bahwa sebenarnya itu adalah salah satu kurikulum tersembunyi (hidden curiculum) yang tak perlu dituliskan dalam silabus maupun Rencana Pelaksanaan Pembelajaran (RPP) pasalnya secara tidak langsung pendidikan karakter itu sudah berlangsung sejak lama dan terjadi dalam kehidupan sehari-hari, ujar guru senior. Berlawanan dengan pendapat guru yang belum berpengalaman yang mengatakan bahwa pendidikan karakter perlu dimasukkan dalam silabus maupun RPP dan dinilai dalam format penilain tersendiri.

Berdasarkan hasil wawancara kepada guru yang berpengalaman dan yang belum berpengalaman sebagai langkah awal dalam penelitian ini. Berpengalaman disini adalah guru yang telah memiliki masa kerja yang lebih banyak di bandingkan dengan guru yang belum berpengalaman, karena massa atau waktu yang dimliki seseorang berpengaruh terhadap banyaknya pengalaman yang diperoleh.

Berdasarkan hal-hal yang telah disebutkan di atas, maka timbul keinginan peneliti untuk mengetahui tentang "Persepsi Guru sekolah dasar dalam Implementasi Pendidikan Karakter di Wilayah III, Kecamatan Kebayoran Baru Jakarta Selatan. 


\section{Pendidikan Karakter}

Ryan (1999: 5) berpendapat bahwa "good character is about knowing the good, loving the good and doing the good". Artinya bahwa karakter yang baik adalah tentang suatu pengetahuan yang baik, kasih sayang, cinta kasih yang baik dan melakukan atau bertindak yang baik. Pendapat tersebut diperkuat oleh Lickona (1992: 51) yang menjelaskan tentang pengertian dan menawarkan satu cara memaknai karakter dalam pembelajaran, sebagai berikut:

"Character consist of operative values, values in action. Character conceived has three interrelated parts: moral knowing, moral feeling and moral behavior. Good character consists of knowing the good, desiring the good and doing the good-habits of the mind, habits of the heart and habits of action".

Pernyataan di atas dapat dijelaskan bahwa karakter terdiri dari nilai-nilai tindakan. Karakter yang dipahami mempunyai tiga komponen saling berhubungan yaitu pengetahuan moral, perasaan moral dan perilaku moral. Karakter yang baik terdiri dari pengetahuan yang baik, menginginkan yang baik dan melakukan kebiasaan yang baik pula dari pikiran, kebiasaan dan tindakan. Lickona (1992: 53) mendefinisikan tiga komponen dalam membentuk karakter yang baik.

Aspek dari tiga komponen karakter adalah: Moral knowing yaitu 1) kesadaran moral (moral awarenees), 2) mengetahui nilai moral (knowing moral values), 3) perspective taking, 4) penalaran moral (moral reasoning) 5) membuat keputusan (decision making) 6) pengetahuan diri (self knowledge). Unsur moral knowing mengisi ranah kognitif siswa. Sedangkan moral feeling, enam hal yang merupakan aspek dari emosi yang harus mampu dirasakan oleh seseorang untuk menjadi manusia berkarakter yaitu: 1) nurani (conscience), 2) penghargaan diri (self esteem), 3) empati (empathy), 
4) cinta kebaikan, kasih sayang (loving the good), 5) kontrol diri (self control) dan 6) kerendahan hati (humility). Moral actions merupakan perbuatan atau tindakan moral dari dua komponen karakter lainnya. Untuk memahami apa yang mendorong seseorang untuk berbuat (act morally) maka harus dilihat tiga aspek lain dari karakter yaitu kompetensi (competence), keinginan (will), dan kebiasaan (habit).

Dapat disimpulkan bahwa untuk mengembangkan karakter melalui tahap pengetahuan (knowing), kemudian berbuat (acting), menuju kebiasaan (habit) dimaksudkan bahwa karakter tidak sebatas pada pengetahuan saja, akan tetapi perlu ada perlakuan dan kebiasaan untuk berbuat sehingga membentuk karakter yang baik. Karena pendidikan karakter merupakan proses untuk membentuk, menumbuhkan, mengembangkan dan mendewasakan kepribadian anak menjadi pribadi yang bijaksana dan bertanggung jawab melalui pembiasaan-pembiasaan pikiran, hati dan tindakan secara berkesinambungan yang hasilnya dapat terlihat dalam tindakan nyata sehari-hari baik di sekolah maupun di masyarakat.

Pendidikan karakter yang terintegrasi meliputi dimensi penting yang dapat digambarkan dalam beberapa tindakan, maksudnya pendekatan pendidikan karakter yang terintegrasi dalam pembelajaran bahwa guru dan siswa bekerja sama dalam proses pembelajaran yang berorintasi pada tindakan yang lebih bermakna.Tujuan Pendidikan Nasional sebagai rumusan kualitas yang harus dimiliki setiap warga negara Indonesia, dikembangkan oleh berbagai satuan pendidikan di berbagai jenjang dan jalur. Tujuan pendidikan nasional memuat berbagai nilai kemanusiaan yang harus dimiliki warga negara Indonesia. Oleh karena itu, tujuan Pendidikan Nasional adalah sumber yang paling 
JIPSINDO No. 2, Volume 1, September 2014

operasional dalam pengembangan pendidikan budaya dan karakter bangsa.

Menurut UU No. 20 Tahun 2003 Pasal 3 menyebutkan Pendidikan Nasional berfungsi mengembangkan kemampuan dan membentuk karakter bangsa yang bermartabat. Ada 9 pilar pendidikan berkarakter, diantaranya adalah:

1. Cinta Tuhan dan segenap ciptaannya

2. Tanggung jawab, kedisiplinan dan kemandirian

3. Kejujuran /amanah dan kearifan

4. Hormat dan santun

5. Dermawan, suka menolong dan gotong royong/ kerjasama

6. Percaya diri, kreatif dan bekerja kerja

7. Kepemimpinan dan keadilan

8. Baik dan rendah hati

9. Toleransi kedamaian dan kesatuan

Berdasarkan tujuan pendidikan nasional, maka pendiikan karakter adalah suatu program pendidikan (sekolah dan luar dekolah) yang mengorganisasikan dan menyederhanakan sumbersumber moral dan disajikan dengan memerhatikan pertimbangan psikologis untuk pertimbangan pendidikan. Tujuan pendidikan karakter adalah mengajarkan nilai-nilai tradisional tertentu, nilainilai yang diterima secara luas sebagai landasan perilaku yang baik dan bertanggung jawab. Nilai-nilai ini juga digambarkan sebagai perilaku moral. Pendidikan karakter selama ini baru dilaksanakan pada jenjang pendidikan pra sekolah/madrasah (taman kanak-kanak atau raudhatul athfāl).

Sementara pada jenjang sekolah dasar dan seterusnya kurikulum di Indonesia masih belum optimal dalam menyentuh aspek karakter ini, meskipun sudah ada materi pelajaran Pancasila dan Kewarganegaraan. Padahal jika Indonesia ingin 
memperbaiki mutu sumber daya manusia dan segera bangkit dari ketinggalannya, maka Indonesia harus merombak sistem pendidikan yang ada, antara lain memperkuat pendidikan karakter.

Strategi pembelajaran yang berkenaan dengan moral knowing akan lebih banyak belajar melalui sumber belajar dan nara sumber. Pembelajaran moral loving akan terjadi pola saling membelajarkan secara seimbang di antara siswa. Sedangkan pembelajaran moral doing akan lebih banyak menggunakan pendekatan individual melalui pendampingan pemanfaatan potensi dan peluang yang sesuai dengan kondisi lingkungan siswa. Ketiga strategi pembelajaran tersebut sebaiknya dirancang secara sistematis agar para siswa dan guru dapat memanfaatkan segenap nilai-nilai dan moral yang sesuai dengan potensi dan peluang yang tersedia di lingkungannya.

Dengan demikian, hasil pembelajarannya ialah terbentuknya kebiasaan berpikir dalam arti peserta didik memiliki pengetahuan, kemauan dan keterampilan dalam berbuat kebaikan. Melalui pemahaman yang komprehensif ini diharapkan dapat menyiapkan pola-pola manajemen pembelajaran yang dapat menghasilkan anak didik yang memiliki karakter yang kuat dalam arti memiliki ketangguhan dalam keilmuan, keimanan, dan perilaku shaleh, baik secara pribadi maupun sosial.

Karakter secara koheren memancar dari hasil olah pikir, olah hati, olah rasa dan karsa, serta olah raga yang mengandung nilai, kemampuan, kapasitas moral, dan ketegaran dalam menghadapi kesulitan dan tantangan. Secara psikologis, karakter individu dimaknai sebagai hasil keterpaduan empat bagian, yakni olah hati, olah pikir, olah raga, dan perpaduan olah rasa dan karsa. Olah hati berkenaan dengan perasaan sikap dan keyakinan atau 
keimanan menghasilkan karakter jujur dan bertanggung jawab. Olah pikir berkenaan dengan proses nalar guna mencari dan menggunakan pengetahuan secara kritis, kreatif, dan inovatif menghasilkan pribadi cerdas. Olah raga berkenaan dengan proses persepsi, kesiapan, peniruan, manipulasi, dan penciptaan aktivitas baru disertai sportivitas menghasilkan karakter tangguh. Olah rasa dan karsa berkenaan dengan kemauan yang tercermin dalam kepedulian. Dengan demikian, terdapat enam karakter utama dari seorang individu, yakni jujur dan bertanggung jawab, cerdas, kreatif, tangguh, dan peduli.

\section{Pengertian Persepsi}

Persepsi sebagai proses yang menyangkut masuknya pesan atau informasi ke dalam otak manusia. Melalui persepsi manusia terus menerus mengadakan hubungan dengan lingkungannya. Hubungan itu dilakukan lewat inderanya, yaitu indra penglihatan, pendengaran, peraba, perasa, dan penciuman (Daryanto, 2010: 77). Persepsi juga diartikan sebagai proses saat individu mengatur dan menginterpretasikan kesan sensoris mereka guna memberikan arti bagi lingkungan mereka (Robbins, Stephen P, 2007: 174-184). Sedangkan pengertian persepsi menurut Rahmat, adalah pengalaman tentang obyek, peristiwa, atau hubunganhubungan yang diperoleh dengan menyimpulkan informasi dan menafsirkan pesan.

Terdapat dua macam persepsi, yaitu External Perception, yaitu persepsi yang terjadi karena adanya rangsangan yang datang dari luar diri individu dan Self Perception, yaitu persepsi yang terjadi karena adanya rangsangan yang berasal dari dalam diri individu. Dalam hal ini yang menjadi objek adalah dirinya sendiri. Dengan persepsi, individu dapat menyadari dan dapat mengerti 
tentang keadaan lingkungan yang ada di sekitarnya maupun tentang keadaan diri individu (Sunaryo, 2004).

Selain itu, persepsi dimaknai sebagai proses yang didahului oleh penginderaan, yaitu suatu stimulus yang diterima oleh individu melalui alat reseptor yaitu indera. Alat indera merupakan penghubung antara individu dengan dunia luarnya. Persepsi merupakan stimulus yang diindera oleh individu, diorganisasikan kemudian diinterpretasikan sehingga individu menyadari dan mengerti tentang apa yang diindera. Dengan kata lain persepsi adalah proses yang menyangkut masuknya pesan atau informasi kedalam otak manusia. Persepsi merupakan keadaan integrated dari individu terhadap stimulus yang diterimanya. Apa yang ada dalam diri individu, pikiran, perasaan, pengalaman-pengalaman individu akan ikut aktif berpengaruh dalam proses persepsi.

Kemudian pengertian persepsi yang dikemukakan oleh Walgito, adalah proses pengorganisasian, penginterpretasian terhadap rangsang yang diterima oleh organisme atau individu sehingga merupakan sesuatu yang berarti dan merupakan aktivitas yang integrated dalam diri individu. Dari berbagai pendapat di atas dapat diartikan bahwa persepsi adalah pemahaman yang dimiliki oleh sesorang dalam melihat sebuah fakta yang terjadi.

\section{Faktor-faktor Yang Mempengaruhi Persepsi}

Menurut pendapat David Krech dan Ricard Crutcfield yang membagi faktor-faktor yang menentukan persepsi menjadi dua yaitu: faktor fungsional dan faktor struktural:

1) Faktor fungsional

Faktor fungsional adalah faktor yang berasal dari kebutuhan, pengalaman masa lalu dan hal-hal lain yang termasuk apa yang kita sebut sebagai faktor-faktor personal. 
Faktor fungsional yang menentukan persepsi adalah obyekobyek yang memenuhi tujuan individu yang melakukan persepsi.

2) Faktor struktural

Faktor struktural adalah faktor-faktor yang berasal sematamata dari sifat stimulus fisik terhadap efek-efek syaraf yang ditimbulkan pada sistem saraf individu. Faktor-faktor struktural yang menentukan persepsi menurut teori Gestalt bila kita ingin memahami suatu peristiwa kita tidak dapat meneliti faktor-faktor yang terpisah tetapi memandangnya dalam hubungan keseluruhan.

Tertarik tidaknya individu untuk memperhatikan stimulus dipengaruhi oleh dua faktor yaitu, faktor internal (kebiasaan, minat, emosi dan keadaan biologis) dan faktor eksternal (intensitas, kebaruan, gerakan, dan pengulangan stimulus).

Faktor eksternal

a) Gerakan, seperti organisme lain, bahwa manusia secara visual tertarik pada obyek-obyek yang bergerak. Contohnya kita senang melihat huruf dalam display yang bergerak menampilkan nama barang yang diiklankan.

b) Intensitas stimuli, dimana kita akan memperhatikan stimuli yang lebih menonjol dari stimuli yang lain.

c) Kebaruan (novelty), bahwa hal-hal baru, yang luar biasa, yang lebih menarik perhatian.

d) Perulangan, hal-hal yang disajikan berkali-kali, bila disertai dengan sedikit variasi, akan menarik perhatian. Disini unsur "familiarity" (yang sudah kita kenal) berpadu dengan unsur-unsur "novelty" (yang baru kita kenal). Perulangan juga mengandung unsur sugesti yang mempengaruhi bawah sadar kita. 
Faktor internal

a) Kebiasaan, kecenderungan untuk mempertahankan pola berpikir tertentu,atau melihat masalah hanya dari satu sisi saja, atau kepercayaan yang berlebihan dan tanpa kritis pada pendapat otoritas.

b) Minat, suatu kondisi yang terjadi apabila seseorang melihat ciriciri atau arti sementara situasi yang dihubungkan dengan keinginan atau kebutuhannya sendiri.

c) Emosi, sebagai manusia yang utuh, kita tidak dapat mengesampingkan emosi, walaupun emosi bukan hambatan utama. Tetapi bila emosi itu sudah mencapai intensitas yang begitu tinggi akan mengakibatkan stress, yang menyebabkan sulit berpikir efisien.

d) Keadaan biologis, misalnya keadaan lapar, maka seluruh pikiran didominasi oleh makanan. Sedangkan bagi orang yang kenyang akan menaruh perhatian pada hal-hal lain. Kebutuhan biologis menyebabkan persepsi yang berbeda.

\section{Metode Penelitian}

Penelitian ini menggunakan metode kuantitatif diskriptif. Penelitian ini dilaksanakan di sekolah dasar yang berada di wilayah III, Kecamatan Kebayoran Baru Jakarta Selatan, yang terdiri dari 10 sekolah dasar negeri dan 1 sekolah dasar swasta. Berdasarkan jumlah populasi sebesar 115 guru, maka akan diambil sejumlah guru sebagai sampel. Sedangkan teknik sampel yang digunakan dalam penelitian ini adalah menggunakan Purposive Sampling. Dalam penelitian ini sampel yang diambil adalah guru yang sudah berpengalaman dan guru yang belum berpengalaman. 
Teknik Pengumpulan Data

Dalam penelitian ini teknik pengumpulan data menggunakan angket. Angket adalah instrumen penelitian berisi serangkaian pertanyaan atau penyataan untuk menjaring data atau informasi yang hasur dijawab responden secara bebas sesuai dengan pendapatnya.

Setelah hasil tes terkumpul, maka tahap selanjutnya adalah tahap analisis data untuk mengetahui ada atau tidaknya perbedaan persepsi guru berpengalaman dan yang belum berpengalaman dalam implementasi pendidikan karakter. Rumus yang digunakan adalah $t$-test

$$
t=\frac{\sqrt[r]{n-2}}{\sqrt{1-r^{2}}}
$$

\section{Hasil Penelitian dan Pembahasan}

Pemahaman awal mengenai pendidikan karakter, sumber informasi adalah kepala sekolah dan guru. Guru menyepakati bahwa pendidikan karakter adalah upaya menanamkan nilai moral kepada siswa, ada perbedaan pandangan terkait integrasi pendidikan karakter dalam mata pelajaran. Dari beberapa sekolah yang diteliti, guru berkesimpulan bahwa pendidikan karakter tidak sekedar diintegrasikan dalam mata pelajaran Pendidikan Kewarganegaraan, Pendidikan Agama, dan Pendidikan IPS, tetapi seluruh mata pelajaran harus mengintegrasikan upaya penanaman nilai-nilai karakter dalam pembelajaran. Sedangkan beberapa guru juga menyatakan bahwa pendidikan karakter hanya bisa diajarkan dalam ketiga mata pelajaran yang berkaitan dengan sosial dan moral, mata pelajaran lain terutama sains dan matematika memungkinkan untuk diintegrasikan dengan pendidikan karakter dalam pembelajaran. 
Pendidikan karakter yang ditanamkan yaitu mengintegrasikan nilai-nilai karakter di setiap mata pelajaran. Strategi yang diterapkan untuk mengintegrasikan nilai-nilai karakter bervariasi, bisa melalui cooperative learning seperti diskusi kelompok, role playing dll. Guru yang mempunyai pengalaman lebih mempunyai strategi yang mudah dan langsung diintegrasikan dalam pembelajaran baik di dalam kelas maupun di luar kelas. Di luar kelas, guru yang berpengalaman lebih mengajarkan bagaimana anak harus bersikap sopan santun, menghormati guru dan teman-temannya. Di dalam pembelajaran nilai-nilai karakter yang dapat dikembangkan seperti kerjasama, menghargai, tanggung jawab, disiplin, teliti dan lain sebagainya.

\section{Persepsi Guru tentang Implementasi Pendidikan Karakter}

Data persepsi guru baik yang berpengalaman maupun yang belum berpengalaman dalam implementasi pendidikan karakter berdasarkan hasil angket. Data yang diperoleh di atas belum dapat di deskripsikan dalam bentuk tendensi sentral, oleh sebab itu data di atas akan dibuat daftar distribusi frekuensi. Berdasarkan data yang diperoleh dalam penelitian secara statistik dengan rumus ttest fisher, diperoleh angka t_hitung $=4,182$ serta t_(tabel ). $(\mathrm{a}=0,05 ; \mathrm{dk}=52)=2.000$. Dengan demikian t_hitung lebih besar dari t_(tabel)(t_hitung >t_(tabel );4,182>2,000).

Dengan demikian H1: Ada perbedaan antara persepsi guru yang berpengalaman dan yang belum berpengalaman dalam implementasi pendidikan karakter (diterima) Ho : Tidak ada perbedaan antara persepsi guru yang berpengalaman dan yang belum berpengalaman dalam implementasi pendidikan karakter (ditolak). 
Hasil analisis data yang telah dilakukan oleh peneliti maka hipotesis di terima berarti ada perbedaan persepsi antara guru yang berpengalaman dan yang belum berpengalaman dalam implementasi pendidikan karakter. Karena angka yang diperoleh dalam penelitian t_hitung lebih besar dari t_(tabel) (t_hitung > t_(tabel );4,182>2,000).

Hal ini sesuai dengan pendapat Endarmoko yaitu pengalaman kata dasarnya "alami" yang artinya mengalami, melakoni, menempuh, menemui, mengarungi, menghadapi, menyeberangi, menanggung, mendapat, menyelami, mengenyam, menikmati, dan merasakan. Sedangkan pendapat Mansur Muslich yaitu pengalaman mengajar adalah masa kerja guru dalam melaksankan tugas sebagai pendidik.

Dalam penelitian kali ini terlihat jelas bahwa ada perbedaan persepsi antara guru yang berpengalaman dan yang belum berpengalaman dalam implementasi pendidikan karakter. Hal ini selain bisa dilihat dari hasil perhitungan t_hitung yang lebih besar dari pada t_(tabel )juga dapat dilihat dari hasil rata-rata skor angket guru yang berpengalaman lebih besar yakni 131,67 sedangkan hasil rata-rata skor angket anak yang diasuh di panti asuhan adalah sebesar 126.5.

Adanya perbedaan persepsi antara guru yang berpengalaman dan yang belum berpengalaman dalam implementasi pendidikan karakter semakin menguatkan bahwa pengalaman adalah guru yang baik. Pengalaman juga sangat berharga bagi setiap manusia pengalaman juga digunakan untuk merujuk pada pengetahuan dan ketrampilan tentang sesuatu yang diperoleh lewat keterlibatan atau berkaitan dengannya selama periode tertentu. Untuk mengetahui perbedaan persepsi guru yang berpengalaman dan yang belum berpengalaman dalam implementasi pendidikan 
karakter. Guru yang berpengalaman lebih memahami bagaimana cara mengintegrasikan nilai-nilai karakter dalam pembelajaran. Dalam proses pembelajaran, guru yang berpengalaman mendapatkan cara dengan sendirinya tanpa harus dituliskan di dalam RPP. Hal ini berbeda dengan guru yang belum berpengalaman bahwa cara mengintegrasikan nilai-nilai karakter masih kesulitan.

Peneliti menggunakan uji hipotesis dengan menggunakan rumus uji t-test fisher. Dengan demikian H1 : Ada perbedaan antara persepsi guru yang berpengalaman dan yang belum berpengalaman dalam implementasi pendidikan karakter (diterima) Ho : Tidak ada perbedaan antara persepsi guru yang berpengalaman dan yang belum berpengalaman dalam implementasi pendidikan karakter (ditolak).

\section{Simpulan}

Berdasarkan hasil penelitian maka dapat disimpulkan bahwa terdapat perbedaan persepsi antara guru yang berpengalaman dan yang belum berpengalaman dalam implementasi pendidikan karakter. Hal ini disebabkan karena guru berpengalaman adalah guru yang sudah menjalani banyak peristiwa dalam hidupnya yang mana berkaitan dalam proses belajar mengajar sehingga membuatnya semakin mengerti pada suatu persoalan dan dapat menyelesaikan dengan tepat. Sebaliknya, guru yang belum berpengalaman adalah guru yang baru saja terjun dalam dunia pendidikan selain itu semakin lama seseorang bekerja menyebabkan guru mengetahui secara lebih mendalam pengalaman yang dialaminya dalam bekerja dan dapat menghindari kesalahan yang mungkin akan terjadi saat bekerja. Hal ini akan berpengaruh positif dalam pngembangan pengalaman 
JIPSINDO No. 2, Volume 1, September 2014

kerja yang dimilki guru tersebut. Hal ini juga bisa dilihat berdasarkan hasil perhitungan secara statistik dari instrumen yang disebarkan yaitu didapat hasil $t_{\text {hitung }}$ yang lebih besar dari pada $t_{\text {tabel }}$.

\section{Saran}

a. Untuk guru berpengalaman yaitu agar mengaplikasikan pengalaman-pengalaman dalam membentuk karakter anak dalam proses pembelajaran.

b. Untuk guru yang belum berpengalaman agar meningkatkan kompetensi dengan pendidikan dan latihan. Pendidikan dan latihan yang dimiliki oleh guru menentukan hasil yang dicapai.

\section{DAFTAR PUSTAKA}

A, Doni Koesoema. 2010. Pendidikan Karakter : Strategi Mendidik Anak di Zaman Global. Jakarta : Grasindo

A, Najib Sulhan M. 2011. Karakter Guru Masa Depan : Sukses \& Bermartabat. Surabaya : Jaring Pena

Aunillah, Nurla Isna. 2011. Panduan Penerapan Pendidikan Karakter di Sekolah. Jogjakarta : Laksana

Daryanto. 2010. Belajar dan Mengajar. Bandung: Yrama Widya.

Danim, Sudarwan . 2011. Pengembangan Profesi Guru : Dari PraJabatan, Induksi, ke Profesional Madani. Jakarta : Kencana

Fakhruddin, Asef Umar. 2011. Menjadi Guru Favorit : Pengalaman, pemahaman, dan Praktek Mewujudkannya. Jogjakarta: DIVA Press

Khan, D. Yahya. 2010. Pendidikan Karakter Berbasis Potensi Diri : Mendongkrak Kualitas Pendidikan. Yogyakarta : Pelangi publishing.

KEMENDIKNAS. 2010. Pengembangan Pendidikan Budaya Dan Karakter Banga: Pedoman Sekolah 
Nur Wahyuni |

Kusuma, Dharma dkk. 2011. Pendidikan Karakter : Kajian Teori dan Praktik di Sekolah. Bandung : Rosdakarya

Muslich, Masnur. 2011. Pendidikan Karakter "Menjawab Tangtangan Krisis Multidimensional”. Jakarta : PT Bumi Aksar

Mu'in, Fatchul Mu'in. 2011. Pendidikan Karakter "kontruksi Teoretik \& praktik". Jogjakarta : Ar-Ruzz Media.

Robbins, Stephen P, 2007. Perilaku Organisasi Buku 1, (Jakarta: Salemba Empat), hal. 174-184(wikipedia.com)

Samani, Muchlas \& Hariyanto, M.S. 2011. Pendidikan Karakter Jakarta : PT Remaja Rosdakarya

Sugiyono, 2011. Metode Penelitian Kuantitatif kualitatif dan R\&D. Bandung : Alfabeta 